\title{
PENERAPAN SISTEM INFORMASI MANEJEMEN DI SEKOLAH
}

\section{Friyen Riswono}

\section{friyenriswono@gmail.com}

\begin{abstract}
Abstrak
Sistem informasi manajemen adalah sebagai satu kesatuan dari komponen komponen atau sub sub sistem yang saling memiliki keterkaitan satu dengan yang lainnya yang mendukung kegiatan manejemen dalam perencaan, pengorganisasian, penggerakan, dan pengendalian dalam menyediakan informasi untuk pengambilan keputusan. Sistem informasi manajemen ini di gunakan untuk menyediakan informasi dalam kegiatan manajemen. Dan di era teknologi ini digunakan dalam penunjang kegiatan manejemen di sekolah seperti penerimaan siswa baru dan juga pembelajaran online atau di sebut e-learning.
\end{abstract}

Kata Kunci : sistem informasi, sistem informasi manajemen, elearning

\section{Latar Belakang Masalah}

Pada saat sekarang ini dimana teknologi informasi sudah menjadi kebutuhan pokok dan juga di gunakan dalam berbagai bidang baik itu belajar, bekerja, dan juga hiburan atau rekreasi. Pada dasarnya sistem informasi manajemen adalah suatu sistem yang menyediakan informasi guna mengambil keputusan dalam manajemen. Dengan sistem informasi ini sangat perlunya pengetahuan bagaimana penggunaannya sehingga dapat dimanfaatkan kelebihan dari sistem informasi manajemen ini terutama di bidang pendidikan yang terkhususnya di sekolah.

Dengan masalah yang di sebutkan diatas maka pokok pembahasan dari tulisan ini adalah apa itu konsep dari sistem informasi manajemen dan bagaimana penerapannya disekolah. 


\section{Pengertian sistem informasi manajemen}

Menurut O’brian (2005) dalam (Yakub, 2012), sistem informasi merupakan kombinasi teratur dari orang orang, perangkat keras (hardware), perangkat lunak (software), jaringan komunikasi, dan sumberdaya data yang mengumpulkan, mengubah, dan menyebarkan informasi dalam sebuah organisasi. Dan menurut Jogiyanto (1999) sistem informasi adalah suatu sistem di dalam suatu organisasi yang memperemukan kebutuhan pengolahan data transaksi harian, mendukung operasi, bersifat manajerial dan kegiatan strategi dari suatu organisasi serta menyediaka pihak luar tertentu dengan laporan lapora yang diperlukan. Sedangkan menurut (Yakub, 2012) sistem informasi merupakan suatu kumpulan dari komponen komponen dalam organisasi yang berhubungan dengan proses penciptaan dan aliran informasi.

Sistem informasi juga dapat di katakan sebagai satu kesatuan dari komponen komponen atau sub sub sistem yang saling memiliki keterkaitan satu dengan yang lainnya yang berhubungan dengan informasi.

Sedangkan manajemen menurut Harold Koontz (1976) dalam (Hartono, 2013) manajemen adalah proses mengupayakan agar segala sesuatu dapat di selesaikan melalui kerja sama orang orang dalam kelompok yang terorganisasi.

Secara umum proses atau kegiatan dalam manajemen terbagi 4 yaitu : planning (perencanaan), Organizing (Pengorganisasian), Actuating (Penggerakan) dan Controlling (Pengendalian/Pengawasan).

Jadi sistem informasi manajemen dapat di katakan sebagai suatu kesatuan dari komponen komponen yang memiliki kesatuan dan berhubungan dengan informasi. Menurut Lucas dalam (Hartono, 2013), sistem informasi manajemen adalah seperangkat prosedur yang tersusun dengan baik, yang pada saat di jalankan, menghasilkan informasi untuk mendukung pengambilan keputusan, dan pengendalian dalam organisasi. Jadi dapat disimpulkan bahwa sistem informasi manajemen adalah sebagai satu kesatuan dari komponen komponen atau sub sub sistem yang saling memiliki keterkaitan satu dengan yang lainnya yang mendukung kegiatan manejemen dalam perencaan, pengorganisasian, penggerakan, dan pengendalian dalam menyediakan informasi untuk pengambilan keputusan. 


\section{Tujuan Sistem Informasi Manajemen}

Sistem informasi manajemen ini secara umum bertujuan untuk menyediakan informasi untuk membantu proses manajemen dalam pengambilan keputusan.

Dalam (V. Agustiandra \& Sabandi, 2019) tujuan sistem informasi manajemen adalah untuk menunjang proses pengambilan keputusan serta meperbaiki proses perencanaan dan pengawasan.

\section{Manfaat Sistem Informasi Manajemen}

Sistem informasi manajemen sangat bermanfaat dalam penyediaan informasi dalam bidang manajemen. Dalam (Purnama, 2016) manfaat sistem informasi manajemen adalah suatu sistem yang menyediakan kepada pengelola organisasi data maupun informasi yang berkaitan dengan pelaksanaan tugas tugas organisasi.

\section{Implementasi Sistem Informasi Manajemen Di Sekolah}

Pada era sekarang ini dimana sudah memasuki Evolusi Industri 4.0 yang dimana teknologi sudah menjadi kebutuhan sehari hari. Bisa digunakan untuk mengelola informasi, mencari informasi, dan semua yang berkaitan dengan informasi. Dengan memanfaatkan sistem informasi ini maka dapat di gunakan untuk membantu kegiatan manajemen di sekolah dalam pengembilan keputusan, mencari informasi dan sebagainya.

Jadi sistem informasi manajemen ini dapat di gunakan dalam mempermudah pengelolaan data siswa di sekolah sebagai berikut :

1. Penerimaan Siswa Baru Secara Online

Jadi dengan penerimaan siswa baru secara online maka mempermudahkan pengelolaan data oleh pihak tenaga kependidikan, selain data sudah tersusun dengan baik data juga sudah terkelompok sesuai dengan jenisnya. Dan karena data sudah berbentuk file jadi lebih mudah dalam penyimpanan dan apabila di butuhkan data juga mudah di temukan.

2. E- Learning

E-learning atau biasa di sebut juga belajar secara online dengan menggabungkan metode tatap muka dengan teknologi pada era evolusi industri 4.0. Dalam (Rochaety, 
2009) proses pembelajaran secara online dapat di selenggarakan dalam berbagai cara berikut.

a. Proses pembelajran secara konvensional (lebih banyak Face to Face meeting) dengan tambahan pembelajaran melalui media interaktif komputer via internet atau menggunakan grafik interaktif komputer.

b. Dengan metode campuran, yakni secara umum sebagian besar proses pembelajaran dilakukan melalui komputer, namun tetap memerlukan face to face meeting untuk kepentingan tutorial atau mendiskusikan bahan ajar.

c. Metode pembelajaran yang secara keseluruhan hanya dilakukan secara online, metode ini sama sekali tidak di temukan face to face meeting.

Jadi, E-Learning adalah sistem pembelajaran secara online dengan menggunakan komputer dan internet yang tidak semuanya bisa dilakukan secara online tapi juga di perlukan juga tatap muka guna memberikan tutotorial.

\section{Kesimpulan}

Jadi sistem informasi manajemen adalah sebagai satu kesatuan dari komponen komponen atau sub sub sistem yang saling memiliki keterkaitan satu dengan yang lainnya yang mendukung kegiatan manejemen dalam perencaan, pengorganisasian, penggerakan, dan pengendalian dalam menyediakan informasi untuk pengambilan keputusan. Kemudian sistem informasi manajemen ini berguna untuk menyediakan informasi dalam pengambilan keputusan. Contoh implementasinya adalah pembelajaran secara online dan juga penerimaan siswa baru secara online. 


\section{Daftar Pustaka}

Hartono, B. (2013). SISTEM INORMASI MANAJEMEN BERBASIS KOMPUTER . Jakarta: Rineka Cipta.

Purnama, C. (2016). SISTEM INFORMASI MANAJEMEN. MojoKerto: Insan Global.

Rochaety, E. d. (2009). SISTEM INORMASI MANAJEMEN PENDIDIKAN. Jakarta: Bumi Aksara.

Yakub. (2012). PENGANTAR SISTEM INFORMASI. Yogyakarta: Graha Ilmu.

V. Agustiandra \& Sabandi, A. (2019). PERSEPSI GURU TERHADAP PENERAPAN SISTEM INFORMASI MANAJEMEN AKADEMIK DI SEKOLAH MENENGAH KEJURUAN (SMK) NEGERI 3 PADANG. Jurnal Bahana Manajemen Pendidikan, 8, 1-8. Retrieved from http://ejournal.unp.ac.id/index.php/bahana 